\title{
On Sporulation in Sulphate-reducing Bacteria
}

\author{
By the late MARY E. ADAMS and J. R. POSTGATE \\ National Chemical Laboratory, Teddington, Middlesex, and Microbiological \\ Research Establishment, Porton, Wiltshire
}

(Received 29 August 1960)

\begin{abstract}
SUMMARY
Enrichment cultures of mesophilic sulphate-reducing bacteria were readily obtained from soils, mud and corrosion products which had been heated to $90^{\circ}$, yet pure cultures of Desulfovibrio desulfuricans were killed by heating to $60^{\circ}$ even when absorbed on dried sterilized soil. Examination of the populations from heated samples revealed exclusively organisms resembling Desulfovibrio orientis; unheated samples contained either $D$. orientis alone or both $D$. orientis and $D$. desulfuricans. The belief that $D$. desulfuricans sporulates is questioned.
\end{abstract}

\section{INTRODUCTION}

Starkey (1988) observed that, though laboratory cultures of mesophilic sulphatereducing bacteria were killed by heat, such organisms could nevertheless be obtained from soils which had been heated to $90^{\circ}$ for ten minutes. Since he was able to demonstrate sporulation among the thermophilic sulphate-reducing bacteria, and since he supported the now obsolete belief that the mesophiles were adapted variants of the thermophiles (see Postgate, 1959a, for references), Starkey concluded that the mesophilic species destulfuricans formed spores in natural conditions but lost this ability after passage in laboratory media. Pochon \& Chalvignac (1952) described a strain which showed such a change on microscopic observation. Starkey proposed the use of the generic name Sporovibrio on this account, but the oblique nature of the evidence for sporulation inhibited wide acceptance of this designation, Desulfovibrio being generally preferred. Prévot (1948), however, retained the name Sporovibrio and, in the third edition of his manual (Prevot, 1957), gave reasons for continuing to retain this generic name and for not accepting the exclusion of the sporulating thermophiles. A mesophilic species showing unequivocal sporulation was isolated by ourselves (Adams \& Postgate, 1959) and named Desulfovibrio orientis. This species is readily differentiated from $D$. desulfuricans by two additional characters: (i) one or two polar or near-polar flagella (Adams \& Postgate, 1959); (ii) absence of a fluorescence reaction typical of $D$. desulfuricans (Postgate, $1959 b$ ); it is distinguished from the thermophile Clostridium nigrificans by its mesophily and by the shape of its spores. It is possible that the heat resistance and sporulation earlier attributed to $\boldsymbol{D}$. desulfuricans was due to the unrecognized presence of $\boldsymbol{D}$. orientis; the present report provides evidence in favour of this view. 


\section{METHODS}

Organisms and cultivation. Desulfovibrio desulfuricans, strain Hildenborough National Collection of Industrial Bacteria (NCIB) 8308, Essex 6 (NCIB 8307) and Beckton (NCIB 8319) were of fresh water origin; strains Canet 41 (NCIB 8393) and El Agheila $\mathbf{Z}$ (NCIB 8880) originated in saline environments and their culture media were supplemented with $2.5 \%(\mathrm{w} / \mathrm{v}) \mathrm{NaCl}$. Stocks were kept in a freeze-dried condition; cultures for routine use were subcultured weekly in medium $\mathbf{C}$ of Butlin, Adams \& Thomas $(1949 b)$ at $30^{\circ}$ under $\mathrm{H}_{2} 99 \%(\mathrm{v} / \mathrm{v})+\mathrm{CO}_{2} 1 \%(\mathrm{v} / \mathrm{v})$. D. orientis, strain Singapore (NCIB 8382), was maintained in a similar manner, but sodium thioglycollate $(0.01 \%, w / v)$ was added to its culture media.

Enrichment cultures of sulphate-reducing bacteria from natural samples were prepared in medium C supplemented with $0.01 \%(w / v)$ sodium thioglycollate and $0.05 \%(w / v)$ ferrous ammonium sulphate, $\mathrm{pH} 7 \cdot 4 \pm 0 \cdot 8$, in $1 \mathrm{oz} .(c .25 \mathrm{ml}$.) stoppered bottles filled to overflowing to exclude air. The thioglycollate ensured that Desulfovibrio orientis would grow if present (Adams \& Postgate, 1959) and it also facilitated growth of $D$. desulfuricans, being below the concentration which showed inhibitory effects (Grossman \& Postgate, 1953).

Diagnostic tests. Enrichment cultures were decanted to give bacterial suspensions reasonably free from $\mathrm{FeS}$ and the fluorescence test for Desulfovibrio desulfuricans (Postgate, 1959b) was performed on the decanted material. Flagella were observed microscopically after Casares-Gil staining. Thermophiles were sought by incubation at $5^{\circ}$. Motility was observed in wet preparations under phase contrast. Heat resistance was tested by sealing $1 \mathrm{ml}$. culture or $1 \mathrm{~g}$. soil in a Durham tube and wholly immersing this in water at $90^{\circ}$ for $10 \mathrm{~min}$. Sterility of treated soils was tested by incubating portions aerobically and anaerobically in the glucose + peptone + yeast extract + salts medium of Postgate (1958).

Pure cultures were not in general isolated from the enrichment cultures. After 8-6 days at $30^{\circ}$, when the enrichment cultures were well blackened and rich in $\mathrm{H}_{2} \mathrm{~S}$, the populations were assigned to Desulfovibrio desulfuricans or $D$. orientis groups according to the following criteria: $D$. desulfuricans, positive fluorescence test, vibrio form, single flagellum, translational motility, failure of subculture to grow at $5^{\circ}$; $D$. orientis, negative fluorescence test, fat vibrio form, more than one flagellum, motility absent or oscillatory, failure of subculture to grow at $55^{\circ}$.

\section{RESULTS}

We have repeatedly confirmed Starkey's observation that soils may be heated to $90^{\circ}$ and still yield enrichment cultures of sulphate-reducing bacteria. On the other hand, the five pure strains of Desulfovibrio desulfuricans mentioned above were all killed when their cultures were heated to $60^{\circ}$ or above for $10 \mathrm{~min}$.; D. orientis usually survived heating to $90^{\circ}$. To see whether soil exerted a protective effect on $D$. desulfuricans, samples which had yielded sulphate-reducing bacteria after heating were sterilized (by autoclaving or by exposure to ethylene oxide at $4^{\circ}$ for $30 \mathrm{~min}$.), dried and then damped with cultures of the Hildenborough strain. The organisms were nevertheless killed when the damped soil was heated to $60^{\circ}$ for $10 \mathrm{~min}$. Since commensal spore-formers might have induced heat resistance in the manner that variants 
of Clostridium sporogenes enhance the heat resistance of Clostridium welchii (Welchia perfringens; Prévot, Raynaud \& Tataki, 1951), three colonial types of sporulating anaerobe were isolated from heated enrichment cultures and mixed with the Hildenborough strain of $D$. desulfuricans. None conferred resistance to $10 \mathrm{~min}$. at $60^{\circ}$. upon it. Desiccation conferred a slightly increased heat resistance: a freeze-dried ampoule of the Hildenborough strain as supplied by the NCIB survived heating to $70^{\circ}$ for $10 \mathrm{~min}$., though others were killed at $80^{\circ}$ and $90^{\circ}$.

It seemed likely that the heat-resistant types of sulphate-reducing bacteria were not of the species Desulfovibrio desulfuricans. Nineteen specimens of natural materials likely to contain these bacteria were collected and enrichment cultures made from them before and after heating for $10 \mathrm{~min}$ at $90^{\circ}$. All yielded flourishing cultures of sulphate-reducing bacteria. These were then assigned to the $D$. desulfuricans or $D$. orientis groups according to the criteria mentioned above. Although the cultures were not pure, and non-sulphate reducing bacteria were present, all the enrichments contained organisms which fell unequivocally into one or the other groups; intermediate types were not found.

Seven samples yielded cultures of the Desulfovibrio desulfuricans group when enriched without heating, but after $10 \mathrm{~min}$ at $90^{\circ}$ they yielded only the $D$. orientis group. The samples tested comprised : corrosion products from a cooling system and a tubercle within a water pipe (cf. Butlin, Adams \& Thomas, 1949a); a sewage sample from the Northern Outfalls Sewage Works, Beckton, London; scrapings from a mild steel plate held $1 \mathrm{ft}$. deep in the Thames at central London; mud samples from the Thames at Teddington and from Byron's pool at Cambridge; a soil sample from Pontardulais, Wales. Twelve specimens yielded the Desulfovibrio orientis group both before and after heating. All these were soil samples originating from: the laboratory grounds (2); a local compost heap; the Roman site at Catterick, Yorkshire (3); Singapore; Buenos Aires; Tanganyika; Hawaii; India (2). No soils of marine or brackish origin were tested. None of the enrichments grew on subculture at $5^{\circ}$.

\section{DISCUSSION}

These observations suggest that the heat-resistant sulphate-reducing bacteria in soils resemble Desulfovibrio orientis rather than $D$. desulfuricans. Consequently, the belief that the latter species sporulates in nature is probably mistaken. The relevance of these considerations to the inclusion of the species desulfuricans in a genus named Sporovibrio is evident.

We should like to draw attention to the fact that the Desulfovibrio orientis group was present in all specimens tested; in a majority of them it was the exclusive type of sulphate-reducing organism. This observation has little statistical value since the number of soils tested was small and their origins were not randomly distributed; nevertheless, it shows an unexpectedly high incidence. We attribute this to the use of thioglycollate in the enrichment media, without which $D$. orientis often fails to grow, whereas growth of $D$. desulfuricans is merely delayed. It seems likely that the D. orientis organism is more ubiquitous than was believed at the time of its isolation.

We are indebted to $\mathbf{M r}$ G. D. Giles for technical assistance with part of this work. The paper is published by the permission of the Director of the National Chemical Laboratory. 


\section{REFERENCES}

Adams, M. E. \& Postgate, J. R. (1959). A new sulphate-reducing vibrio. J.gen. Microbiol. 20, 252.

Butun, K. R., Adams, M. E. \& Thomas, M. (1949a). Sulphate-reducing bacteria and internal corrosion of ferrous pipes conveying water. Nature, Lond. 163, 26.

Butlin, K. R., Adams, M. E. \& Thomas, M. $(1949 b)$. The isolation and cultivation of sulphate-reducing bacteria. J. gen. Microbiol. 3, 46.

Grossman, J. P. \& Postgate, J. R. (1953). The estimation of sulphate-reducing bacteria (D. desulphuricans). Proc. Soc. appl. Bact. 16, 1.

Pochon, J. \& Chalvignac, M. A. (1952). Sur l'instabilité des caractères d'une souche de Sporovibrio. Ann. Inst. Pasteur, 82, 399.

Postgate, J. R. (1953). On the nutrition of Desulphovibrio desulphuricans: a correction. J. gen. Microbiol. 9, 440.

Postante, J. R. (1959a). Sulphate reduction by bacteria. Annu. Rev. Microbiol. 13, 505.

Postgate, J. R. (1959b). A diagnostic reaction of Desulfovibrio desulfuricans. Nature, Lond. $183,481$.

Prévot, A.-R. (1948). Manuel de classification et de détermination des bactéries anaerobies, 2nd ed. Paris: Masson et Cie.

Prévot, A.-R. (1957). Manuel de classification et de détermination des bactéries anaerobies, 3rd ed. Paris: Masson et Cie.

Prévot, A.-R., Raynaud, M. \& Tataki, H. (1951). Recherches sur la thermorésistance des $\mathrm{Cl}$. sporogenes et le phénomène d'entraînement des espèces peu résistantes. Ann. Inst. Pasteur, 80, 553.

STARKEY, R. L. (1938). A study of spore formation and other morphological characteristics of Vibrio desulfuricans. Arch. Mikrobiol. 9, 268. 